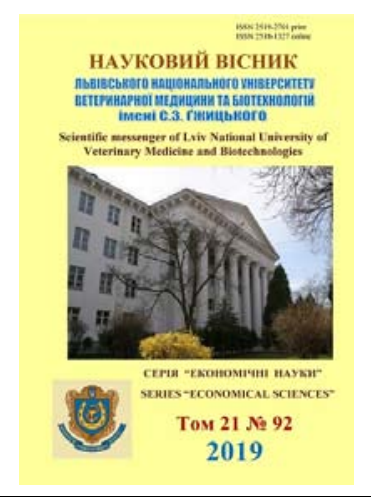

\section{Науковий вісник Дьвівського національного університету ветеринарної медицини та біотехнологій імені С.3. Гжицького. Серія: Економічні науки}

\author{
Scientific Messenger of Lviv National University \\ of Veterinary Medicine and Biotechnologies. \\ Series: Economical Sciences
}

ISSN 2519-2701 print

\title{
Non-agricultural activities as a measure of revitalisation of rural areas
}

\author{
B. Batyuk ${ }^{1}$, N. Kudla ${ }^{2}$ \\ ${ }^{1}$ Stepan Gzhytskyi National University of Veterinary Medicine and Biotechnologies Lviv, Ukraine \\ ${ }^{2}$ Lviv University of Trade and Economics, Lviv, Ukraine
}

Article info

Received 08.02.2019

Received in revised form 11.03.2019

Accepted 12.03.2019

Stepan Gzhytskyi National University of Veterinary Medicine and Biotechnologies Lviv, Pekarska Str., 50, Lviv 79010, Ukraine. Tel.: +38-068-885-31-99 E-mail:bbbatyk@gmail.com

Lviv University of Trade and Economics, TuganBaranovs 'kogo Str., 10, Lviv 79005, Ukraine. Tel.: +38-098-583-35-60 E-mail:kudlan@ukr.net
Batyuk, B., \& Kudla, N. (2019). Non-agricultural activities as a measure of revitalisation of rural areas. Scientific Messenger of Lviv National University of Veterinary Medicine and Biotechnologies. Series: Economical Sciences, 21(92), 120-124. doi: 10.32718/nvlvet-e9220

A latest vision of the development of rural areas should include an increase of productive capacities of the agrarian sector in conjunction with the development of non-agricultural activities through the revitalisation of local entrepreneurship. In the process of stabilisation of the situation in agricultural industry, the priority of raw material sectors will be reduced in relative terms to tip the balance in favour of processing operations and the provision of services, including tourism. This poses new challenges to rural residents, local authorities, non-governmental organisations, and education and science professionals to revitalise economic activities in rural areas. The observations made and surveys conducted by the author are an attempt to make a case for the importance of diversification of the operations of business entities in rural areas with reference to international experience. Research has made it possible to identify both objective and subjective factors that prevent the revitalisation of entrepreneurship in rural areas, specifically, the low purchasing power of rural residents and their quality of life, fully dilapidated technical infrastructure, significant transport costs, and poor implementation of public programmes.

Key words: destinations, multifunctional development, tourist services, revitalisation of business.

\section{Несільськогосподарська діяльність як вимір активізації сільських територій}

\author{
Б.Б. Батюк ${ }^{1}$, Н.С. Кудла ${ }^{2}$ \\ ${ }^{1}$ Львівський національний університет ветеринарної медицини та біотехнологій імені С.3. Гжсицького, \\ м. Львів, Україна \\ ${ }^{2}$ Львівський торговельно-економічний університет, м. Львів, Украӥна
}

Сучасне бачення розвитку сільських територій повинно стосуватися підвищення виробничого потенціалу аграрного сектора в поєднанні з розвитком несільськогосподарської діяльності шляхом активізації місиевого підприємництва. В процесі стабілізації ситуації у сільському господарстві ранг галузей сировинного характеру буде відносно зменшуватися на користь переробних галузей і надання послуг, в тому числі туристичних. Це становить нові виклики перед селянами, органами місиевого самоврядування, громадськими організаціями, працівниками освіти та науки на предмет активізації господарської діяльності на сільських територіях. Спостереження автора та проведені анкетні дослідження становлять спробу аргументувати важливість диверсифікачії діяльності суб'єктів господарювання у сільській місиевості, вказуючи на аналогію закордонної практики. Дослідження виявили об 'єктивні й суб 'єктивні чинники, які не дозволяють активізувати підприємництво у сільській місчевості, а саме, низька купівельна спроможність сільських жителів й якість їх життя, повністю зношена технічна інфраструктура, значні транспортні витрати, незадовільна реалізація державних програм.

Ключові слова: дестинації, багатофункціональний розвиток, туристичні послуги, активізація підприємницької діяльності.

Сучасний європейський розвиток сільських територій стоїть перед багатьма викликами, як зовнішніми, так і внутрішніми, які мають важливе значення не тільки для селян і сільськогосподарських товаровиро- бників, але й для споживачів і платників податків. Ці виклики полягають у переосмисленні цілей аграрної політики, форм іiі розвитку і реалізації. Еволюція спільної сільськогосподарської політики Європейського 
Союзу показує на чіткий відхід від типово галузевої аграрної політики до спрямованої на багатофункціональність політики розвитку села, істотним елементом якої є збалансований і сталий розвиток сільського господарства та інших галузей агропромислової економіки, суспільний розвиток і збереження навколишнього природного середовища, історико-культурної спадщини (Adamowicz, 2005).

Концепція багатофункціонального розвитку сільських територій та позавиробничих функцій сільського господарства вимагає пошуку методів оцінки цих функцій, калькулювання та знайдення відповідних способів винагородження селян за їх вклад у збереження і формування природного, культурного середовища, сільських краєвидів, традицій, що демонструють відкритість і гостинність сільського простору. Сучасне сільське господарство повинно інтегруватися у систему збалансованого і сталого розвитку сільських територій, а зі зміною державної аграрної політики, вступом у СОТ та набуттям асоційованого членства в СС може скористатися з інших видів фінансової й технічної допомоги.

Українські науковці добре розуміють, що для сталого розвитку АПК особливу увагу необхідно приділити подоланню соціального занепаду села і забезпеченню комплексного соціально-економічного розвитку сільських територій в контексті економічної безпеки країни (Vasyltsiva \& Boika, 2016). При цьому повинні одночасно розв'язуватися дві групи завдань: перша - прискорення розв'язання актуальних соціальних проблем аграрного сектора економіки i, в ширшому плані, села загалом, як середовища життєдіяльності третини громадян України; друга - формування виробничої і соціальної сфери сільських територій за моделлю багатофункціонального розвитку, яка притаманна постіндустріальним країнам.

Розвиток сільських територій в основному полягає у диференціації сільського господарства, а отже, відході від монофункційності, яка, як правило, полягає у виробництві сільськогосподарської продукції. Однак можна стверджувати, що традиційне село завжди було багатофункціональним, тільки у дещо іншому значенні, ніж сьогодні. Давня багатофункціональність полягала в тому, що поза виробництвом сільськогосподарських продуктів його мешканці виготовляли значну частину засобів праці (господарський реманент, корми, будівельні матеріали тощо), самі забезпечували більшість потрібних їм засобів споживання, а також виробничих і побутових послуг. Така багатофункціональність, перш за все, була зосереджена навколо сільськогосподарського підприємства і виходила 3 характеру селянського господарства. Традиційний селянин вимушений був бути, в силу обставин, багатофункціональним.

Сучасний багатофункціональний розвиток полягає у запровадженні в сільський простір нових функцій, не пов'язаних із сільським господарством. Головною метою багатофункціонального розвитку сільських територій є незмінне поліпшення умов життя, праці і відпочинку селянських родин, надання несільськогосподарських послуг (сільський чи екологічний туризм). Рушійною силою такого розвитку може бути модерні- зація або будова нової суспільно-економічної інфраструктури на селі, яка сприятиме розвитку несільськогосподарської діяльності на сільських територіях при одночасному розширенні зайнятості місцевого населення. Акцентування традиційним селом нових, неаграрних функцій сприятиме зменшенню безробіття, а також розвитку підприємництва, яке $є$ умовою кожного виробничо-економічного росту (Wilkin, 2013).

Практика свідчить, що багатофункціональний розвиток сільських територій у розвинутих країнах був результатом і зусиллям багатьох інституцій, особливо якщо цей процес стосувався слаборозвинутих регіонів, тобто з великим рівнем безробіття, незадовільною інфраструктурою i депопуляційними проблемами. Процесом створення нових робочих місць, нових джерел доходів сільського населення, розвитком підприємництва, тобто господарською активізацією сільських територій, займаються спеціалізовані урядові агенції при підтримці бюджетного фінансування, а також свої пропозиції висловлюють громадські установи, приватні організації, які співпрацюють з місцевими адміністраціями.

В Україні і у країнах європейського співтовариства можна виокремити сільські райони, які розвиваються динамічно і швидко, а населення, яке проживає в них, одержує доходи вищі, ніж у середньому в країні. Однак частка таких територій незначна у державному масштабі. Більшість сільських територій становлять райони господарської стагнації, або так званого безперспективного розвитку, які розглядалися владою як непотрібні через їх територіальне розміщення, у той час коли економічний розвиток міст відбувався швидкими темпами. Політика країн Європейського Союзу спрямована на збереження територіальних одиниць, сприяє їх розвитку, залучаючи різноманітні структурні фонди, програми, про що свідчать високі життєві стандарти сільського населення та їх побутові умови.

Багатофункціональний характер сільських територій $є$ концепцією формування стратегії розвитку села, зокрема підтримки несільськогосподарської діяльності його мешканців. Основу такого розвитку становить, перш за все, місцеве підприємництво, яке спрямоване на різні форми залучення капіталу, з одного боку, розширення аграрної діяльності і розвиток інших чи нових сільськогосподарських напрямів виробництва, а 3 другого - становлення бізнесу, не пов'язаного 3 аграрним сектором місцевої економіки. Підприємництво в аграрній сфері характеризується розвитком виробництва основних продуктів сільського господарства, нетрадиційної (альтернативної) продукції рільництва, іiі переробки, виробничим обслуговуванням сільського господарства. Несільськогосподарська сфера включає розвиток комунальних послуг, торгівлю, промислові виробництва на місцевій сировині, а також обслуговування соціально-культурної та туристичної інфраструктури. Отже, багатофункціональний розвиток полягає у диференціації сільської економіки, вмілому запровадженні у сільський простір щораз більше функцій несільськогосподарського призначення. Розбудова малого і середнього виробництва, його 
модернізація, особливо заготівельно-переробного характеру, народних ремесел, послуг, інфраструктури тощо на сільських територіях сприятиме професійній активізації населення, яке 3 часом відходитиме від сільськогосподарського виробництва. Такі процеси пришвидшать структурні зміни у сільському середовищі, впливаючи тим самим на піднесення аграрної сфери на вищий та якісніший щабель господарювання, що так важливо з погляду перспективи інтеграції України у СОТ та вступу до Євросоюзу.

Створення нових робочих місць на сільських територіях $€$ основною умовою підвищення суспільновиробничого потенціалу країни. При цьому проблеми села і сільського господарства повинні розглядатися комплексно, оскільки існують залежності між модернізацією сільського господарства та багатофункціональним розвитком сільських територій. Створення можливостей та умов праці для тих, хто бажає відмовитись від ведення сільськогосподарської діяльності, але має наміри постійно проживати у селі, потрібно окремо розглядати у національній стратегії, а на вирішення таких завдань повинні виділятися бюджетні засоби.

Є багато причин, які змушують селян займатися не тільки сільським господарством, а й іншою господарською діяльністю у менших масштабах. Однак найважливіша причина виходить 3 ринкових принципів конкуренції: щороку стає менше власників селянських і фермерських господарств та інших підприємств різних організаційно-правових форм господарювання, які утримуються виключно з доходу, одержаного від сільськогосподарської діяльності, а тим більше тих, хто одержує стабільні доходи.

Проведені наукові дослідження $з$ цієї проблематики дозволили оцінити перспективи ведення господарської діяльності у вибраних сільських територіях передгірських і гірських районів Львівської області. Анкетуванням було охоплено 109 суб'єктів, які функціонують у привабливих туристичних дестинаціях. Для дослідження суб’єкти підприємницької діяльності вибирались випадково, а також за допомогою й сприянням органів місцевої влади. Зібраний у такий спосіб матеріал було відповідно систематизовано й опрацьовано.

Значна частина респондентів 94\% зазначила свою невдоволеність 3 веденої діяльності. До основних причин такої ситуації анкетовані вказали низькі доходи, значні інвестиційні вкладення та висока праце місткість продукції, тобто витраченого часу на одиницю продукції чи наданні послуг. Відповіді місцевих підприємців виразно вказували на потребу покращення окупності веденої діяльності.

Незважаючи на декларовані проблеми, низьку рентабельність та несприятливі умови ведення господарської діяльності на сільських територіях 76\% від загальної кількості опитаних респондентів мають намір і надалі займатися своєю дотеперішньою діяльністю, $17 \%$ швидше за все не планують розглядати інші форми діяльності й вірогідно не будуть впроваджувати кардинальних змін. Структуру відповідей на питання, що стосується намірів щодо напрямів майбутньої діяльності представляє рис. 1.

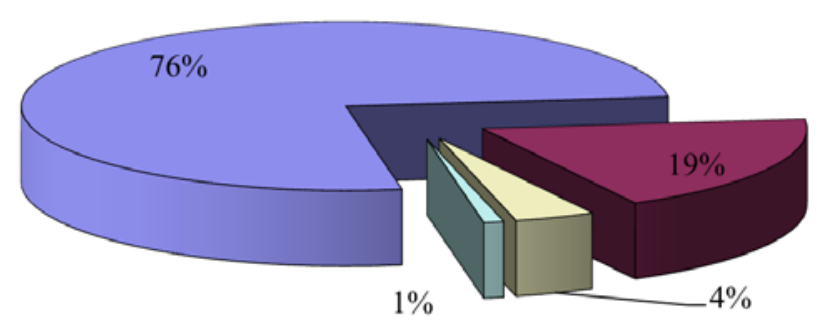

口Не маю наміру змінювати діяльність

口Швидше не змінюватиму профіль діяльності

口Планую змінити діяльність

口Рішучі наміри на зміни діяльності

Рис. 1. Наміри респондентів щодо ставлення до господарської діяльності

У досліджуваній сільській місцевості переважають дуже малі господарські суб'єкти - магазини, як правило продовольчі, досить примітивні обслуговуючі підприємства, пилорами, пункти прокату спортивнотуристичного спорядження, особисті селянські господарства, які надають туристичні послуги, ведення яких не вимагає значних інвестиційних витрат та висококваліфікованих спеціалістів. Переважна кількість власників малих підприємств - це люди, які не характеризуються виробничою експансією. Однак у цій великій кількості сільських підприємців знайдуться активні особистості, що в недалекому майбутньому зможуть підвищити ефективність очолюваної фірми. Адже відомо, що 1 грн., отримана у сфері сільського господарства, забезпечує роботою 12 грн. в інших сферах життєдіяльності суспільства - постачання, зберігання, переробки, харчування тощо (Rarok, 2011). До малого сільського бізнесу необхідно ставитися відповідально, адже він може відігравати важливу роль у розвитку сільських територій.

Реалізація концепції збалансованого розвитку сільських територій, диверсифікаційні процеси в аграрній сфері, розвиток несільськогосподарських функцій сільських територій повинні стати предметом розгляду урядових структур і відповіддю на наявні труднощі, а також на затяжну кризову ситуацію українського села. Ключова проблема багатьох сіл полягає у забезпеченні працевлаштування безробітних, особливо працездатних жінок та молоді. Завданнями місцевої влади і центральних державних органів є створення сприятливих умов для розвитку різних форм малого і середнього підприємництва.

До основних перешкод розвитку малого підприємництва на сільських територіях можна віднести (Cherven, 2010):

- відсутність єдиної, поетапно реалізованої стратегії та тактики розвитку малого бізнесу на сільських територіях;

- недостатність фінансових ресурсів органів місцевого самоврядування для формування належної інституційної інфраструктури підтримки та розвитку підприємництва;

- недостатній досвід, навики та рівень підготовки представників органів державного управління щодо реалізації проектів розвитку малого підприємництва; 
- низький рівень розвитку транспортної, соціальної та ринкової інфраструктури у сільській місцевості;

- недостатність навиків ведення підприємницької діяльності, нестача фінансових ресурсів населення у сільській місцевості щодо започаткування та ведення підприємницької діяльності;

- відсутність дієвих програм залучення коштів вітчизняних трудових мігрантів у підприємницьку діяльність;

- чинник трансформаційної кризи (неспроможність сільськогосподарських підприємств, демографічна криза тощо);

- пасивність органів місцевого самоврядування в участі міжнародних проектах з активізації підприємницької діяльності на сільських територіях.

За таких обставин необхідно ретельно проаналізувати наявний потенціал для розвитку бізнесу, зокрема сімейного, найбільш прийнятного для сільської місцевості. Перспективними напрямами розвитку малого бізнесу на досліджуваних сільських територіях $є$ бджільництво, розведення ставкової риби, вирощування лікарських рослин, міні переробка продуктів рослинництва i тваринництва, надання туристичних послуг, придорожній сервіс та народні промисли.

Сільські території гірських і передгірських перебувають у різних умовах щодо можливостей ведення на своїх теренах несільськогосподарської діяльності. Фактор селянської ментальності, який залишився 3 часів централізованого управління, створює великі перешкоди підприємництву. Місцева влада і локальні спільноти надалі очікують допомоги ззовні, не розуміючи, як багато залежить від них самих. Вміле використання потенціалу розташування, зовнішня реклама місцевості, залучення родинних та інших інвесторів, входження у ринкові ніші, звичайно не прості завдання, але й не неможливі щодо виконання.

Важливим заходом щодо вирішення проблеми розвитку сільських територій $є$ схвалення концепції “Державної цільової програми сталого розвитку сільських територій на період до 2020 року”, в якій зазначається, що оптимальним варіантом розв'язання цієї проблеми $\epsilon$ “створення правових, фінансових та організаційних умов для реалізації багатофункціональності сільського господарства, формування конкурентоспроможного аграрного сектору, диверсифікації (різнобічний розвиток) виробництва й зайнятості сільського населення, сприятливих агроландшафтів, якісного середовища проживання людей у сільській місцевості та розвитку партнерства держави, бізнесу, територіальних громад” (Програма). Концепція передбачає шляхи і способи розв'язання проблем сільських територій. Так, зокрема, планується створення сприятливих умов для проживання населення на сільських територіях шляхом впровадження соціальних стандартів і нормативів відповідно до європейських, розвиток об’єктів соціальної інфраструктури, сприяння створенню комунальних підприємств для побутового обслуговування сільського населення та благоустрою сільських населених пунктів, підвищення якості освітніх послуг, розвиток сільського аграрного туризму, народних промислів, підприємництва, розвиток орга- нічного сільськогосподарського виробництва, організація оптово-роздрібних ринків сільськогосподарської продукції тощо.

Результати проведеного аналізу несільськогосподарської діяльності у вибраних гірських та передгірських територій показав, що у Львівській області сформувалися дестинації, які диференційовані за економічним й соціальним розвитком. Щоб уникнути деградаційних процесів, чи утримати дотеперішній рівень розвитку суб'єкти господарської діяльності змушені шукати інших джерел доходу поза сільським господарством.

Проведені анкетні дослідження засвідчили, що умови для ведення несільськогосподарської діяльності $є$ досить складними. До причин, що обмежують прийняття цієї діяльності на сільських територіях можна віднести: низька купівельна спроможність сільських жителів й якість їх життя, повністю зношена технічна інфраструктура, значні транспортні витрати, незадовільна реалізація державних програм тощо. За найсуттєвіше обмеження, що ускладнює ведення власної господарської діяльності респонденти вказали відсутність або недостатність фінансових, технічних та матеріальних засобів й відсутність підтримки та гарантій з боку державних інституцій. Окрім цього несільськогосподарська виробнича чи послугова діяльність вимагає відповідних вмінь та компетентностей місцевих підприємців, які шукатимуть консультаційних на навчальних послуг.

Подальший розвиток несільськогосподарської діяльності вимагає ведення активної державної політики зі сприяння сільському підприємництву, модернізації та розбудові інфраструктури, створенні сприятливих інвестиційних умов для малого та середнього бізнесу. Можна вважати, що підприємницькі ініціативи будуть скеровані на нові ринкові ніші, що відповідає вимогам ринкової економіки. Несільськогосподарська діяльність становить один 3 найвагоміших елементів альтернативних доходів сільських жителів та господарську активізацію сільських територій. Однак, процес гармонійного розвитку сільських територій повинен розглядатися у багатьох аспектах, із яких сільське господарство є головним, але не основним.

\section{References}

Adamowicz, M. (2005). Perspektywiczne kierunki ewolucji wspólnej polityki rolnej. Roczniki Nauk Rolniczych. Seria G: Ekonomika Rolnictwa, 90(1), 18-31.

Cherven, I.I. (2010). Rozvytok ekonomiky silskykh terytorii. Transformatsiia silskoho hospodarstva ta sela: yuvileinyi zb. nauk. stat. Lviv: Ukrainski tekhnolohii, 209-217 (in Ukrainian).

Hubeni, Yu.E. (2007). Rozvytok silskykh terytorii: deiaki aspekty yevropeiskoi teorii i praktyky. Ekonomika Ukrainy, 4, 62-71 (in Ukrainian).

Rarok, O.V. (2011). Rol malykh pidpryiemstv u rozvytku silskykh terytorii. Visnyk Kamianets-Podilskoho nats. un-tu im. I. Ohiienka. Ekonomichni nauky. Kamianets-Podilskyi: FOP Sysyn O.V., 4, 263-267 (in Ukrainian). 
Sabluk, P.T. (2005). Kardynalni napriamy vyrishennia ekonomichnykh problem v APK. Ekonomika APK, 5, 3-8 (in Ukrainian).

Vasyltsiva, T.H., \& Boika, V.V. (2016). Napriamy ta zasoby rozvytku silskykh terytorii $\mathrm{v}$ konteksti zmitsnennia sotsialno-ekonomichnoi bezpeky
Ukrainy: [monohrafiia]. Lviv: Liha-Pres (in Ukrainian).

Wilkin, J. (2013). Podstawy strategii zintegrowanego rozwoju rolnictwa i obszarów wiejskich w Polsce. Uniwersytet Warszawski, Wydział Nauk Ekonomicznych: Warszawa. 